Journal of Money and Economy

Vol. 16, No. 1, Winter 2021

pp. $115-134$

DOI: 10.29252/jme.16.1.115

Original Research Article

\title{
A Stepwise Model of Customer Experience Management for Iranian ICT Sector
}

\author{
Fatemeh Saeedi" \\ Abolfazl Danaei ${ }^{\dagger}$ \\ Seyyed Mohammad Zargar *
}

Received: 23 Jan 2021

Approved: 07 Jul 2021

Knowing and managing the concept of customer experience is the main factor in creating competitiveness for any organization. Moreover, without customer experience management, a business cannot specify appropriate strategies to maintain the current market and business sustainability. However, most of the existing studies have looked at this subject abstractly and have not provided a comprehensive model based on steps taken in the customer journey. This research aims to fill the gap by providing the body of knowledge with a comprehensive model for customer experience management, where the stepwise nature of the concept is maintained. Using a grounded theory (GT) strategy, 20 experts in the Iranian IT sector took part in this study. Data gathered using an interview protocol that was made based on reviewing the existing literature. Both reliability (Inter-coder rating) and validity (face and content validity) measures for the data gathering tool were obtained. Three coding approaches of grounded theory (open, axial, and selective coding) were applied to analyze the data. This study introduced a stepwise model of customer management experience through the customer journey steps. The model also contains the prerequisites conditions to realize the customer experience in the IT sector and reveals the contextual factors affecting the process and finally the consequences of applying the model.

Keywords: Customer Experience Management; Stepwise Model; Customer Journey. JEL Classification: M31

\footnotetext{
* Department of Management, Semnan Branch, Islamic Azad University, Semnan , Iran, f.saeedi@mci.ir

$\uparrow$ Department of Management, Semnan Branch, Islamic Azad University, Semnan, Iran, a.danaei@semnaniau.ac.ir (Corresponding Author).

\$ Department of Management, Semnan Branch, Islamic Azad University, Semnan, Iran, m.zargar@ semnaniau.ac.ir
} 


\section{Introduction}

Customer experience is considered a competitive basis for businesses in today's world. Based on a study by Gartner (2017), four out of every five organizations are expected to compete on customer experience during two years (Klink et al., 2018). The economic advantages of competition on customer experience are obvious. On average, those organizations with superior customer experience will grow five times faster than those who have been weak in this respect (Forrester, 2017). Also, more than 80 percent of consumers are willing to pay more to obtain a better experience (Capgemini, 2017). Regarding the costs, effective customer experience management can help an organization to save hundreds of million dollars. For example, having removed the problems which annoyed the customers, Sprint managed to decrease 1.7 billion dollars of its costs per year (Forrester, 2017).

While customer experience management is very tempting for organizations, the evidence shows that most of the time, it is not properly implemented in organizations or implemented in just one section of the firm. For example, $90 \%$ of organizations believe that holding customer orientation as a culture is an important principle; however, only $15 \%$ consider themselves effective in providing customer experience (Harvard Business Review, 2017). On the other hand, such a gap exists among customers as well. Three-quarters of organizations believe that they are customer-oriented; however, only $30 \%$ of customers believed the same (Capgenmini, 2017).

The improvement of customer experience is mainly the responsibility of marketing experts since the main part of organizations' budgets focuses on improving customer experience management by the marketing department (Gartner, 2018). Many researchers and authorities believe that customer communications management has not satisfied some levels of expected value for customers and the profitability for organizations. And customer experience management can be considered a combined framework overcoming the theoretical and practical obstacles and restrictions regarding customer communications management (Palmer, 2010). Customer experience, in most cases, plays a more significant role than the services provided and includes stages before and after rendering services. Organizations are looking for some mechanisms to create customer communication in stages previous to and during the consumption. They actively perform participatory activities with customers during the post-consumption stages (Kandampully and Solnet, 2015). 
Nowadays, organizations are making an effort to take advantage of customers as contributors and brand promoters. So, the investigations in customer experience management have to examine the customer journey with all of its dimensions. The progress made in the Internet and technology has helped to increase the importance of interaction and communication between organizations and customers (Nambisan and Baron, 2007). Understanding customer experience and making sure that this experience is being managed effectively at every point of the interaction between the organizations and customers has turned out to be a key target for those organizations that aim to advance the market. The question that is usually asked is whether organizations are actually providing the experience expected by customers or not and whether the organizations have taken into consideration any programs to manage such experience regarding all the changes in the world of communication and technology. Paying attention to this case and creating a mechanism to satisfy customers' expectations from organizations are vital (Kandampylly et al., 2018).

So far, the existing literature in the field of customer experience management has dealt with the different aspects of customer experience; however, no comprehensive model is addressing the underlying factors, strategies, causal conditions, and consequences of customer experience management in the literature. The concept of customer experience management itself remains a blur; the lack of an applied model to translate into the daily tasks of organizations is an apparent issue. This study explores the exact steps of customer experience management during the customer journey to address the issue. The first part of the article includes some introduction about customer experience and the research background is supported in section 2. The third section includes research methodology. In the fourth section all interviews and their results such as data and final model of customer experience management for Iranian ICT sector are extracted. In the fifth section discussion, conclusion and recommendations are mentioned.

\section{Research Background}

The concept of customer experience management has been investigated by Marutschke et al. (2019). According to them, customer experience management is a relatively new field of research. Although previous studies have examined especial aspects and elements of customer experience, they still could not provide a plausible answer to some fundamental questions, including how touchpoints in the customer journey are combined and how customer experience is measured in a way that its multidimensional nature 
would be taken into consideration. Zaki and Neely (2019) suggest that creating a valuable customer experience is an organization's strategic priority. Their study helps to analyze text data related to customer communication management and those extracted from social media. Their presented model, which was based on text mining, has been recommended to organizations. (Zaki and Neely, 2019)

To gain customer experience insights, McColl-Kennedy et al. (2019) provided a new conceptual model of the customer experience through studying all previous research so that customer experience would be better understood and managed regarding elements of creating value (resources, activities, background, interactions, and the role played by customer), cognitive answers, and feelings about touchpoints all over the customer journey. However, Kandampully et al. (2018) studied customer experience in the service sector to obtain customer loyalty and, finally, competitive advantage. They aimed at the progress of scientific studies in customer experience management (CEM) in relation to provision of services through a general overview of the main elements of customer experience management. The study has provided a framework for customer experience management as well as a rich research agenda. Based on their model, researchers recommended a holistic approach regarding customer experience management through cooperation between marketing, designing, production operation, human resources, and strategy and connection with technology and social media. Kandampully et al. (2018)

Customer experience management is one of the most promising approaches towards marketing, which has made some people call it the "future of marketing." Klink et al. (2018) reviewed marketing courses by considering the nature of customer experience. They have provided some potential adaptations and their approach, including training customer experience management in courses available, making components limited in the field and making some changes in one course of complementary level of education. Homburg et al. (2017) evaluated customer experience management as one of the most promising marketing approaches in consumer industries. For them, the concept of customer experience management has not been well understood. Here, customer experience management has been introduced as a high-level resource of cultural mentality towards customer experiments, strategic orientations to design customer experience, and organizational capabilities to renew them continuously to achieve long-term customer loyalty and maintain it. The authors in this study have provided four distinct patterns of the concept. The authors believed that customer experience management is 
an evolutionary concept requiring more study and evaluation in different organizational fields.

Moreover, Hwang and Seo (2016) studied the concept in another study. Their study provided insights on the definitions, dimensions, and concepts involved in customer experience management, and the evolution of customer experience management research from a theoretical perspective has been dealt with. They believed that the methodological approaches used in customer experience management studies had been dealt with, and challenges regarding customer experience measurement had been studied. Finally, the study presented the cultural problems in customer experience management researches.

The Lack of a step-by-step approach in available studies, especially in those conducted in the Iranian context, is salient. Hakimi et al. (2019) studied customer experience management, aiming mainly at identifying factors managed by organizations to form customer experience in person in the retail banking industry. They categorized the elements of the customer experience into nine main categories and 33 subcategories. Six main levels were also identified. The nine main categories are interacting with customers, employees, accountability, branches, brand, services, processes, social environment, and extraordinary experience. The research could create a more comprehensive perspective in terms of how customer experience is created. According to the results, the main categories of customer experience and how these indices affect each other have been identified (Hakimi et al., 2019).

The concept of customer experience also can be traced, although weekly, in relationship with other concepts. Rahimi et al. (2019) attempted to design and explain loyalty based on customer experience in the hotel management industry. They showed that the final model consists of 6 general categories, 14 subcategories, and 54 main concepts. Also, the results showed that categories of quality of hotel employees, quality of the physical environment, and quality of service rendering functions are effective causal factors on customers' perceptions and expectations, which provide customers with multiple value creation strategies. The outcomes of this value creation will determine the loyalty level (Rahimi et al., 2019).

In research by Heshmati et al. (2019) titled "training appropriate model of customer experience management with an emphasis on related indices in the bank training system," customer experience management has been studied. The research aims to design and train an appropriate model of customer experience management with emphasis put on related indices in terms of bank services. A qualitative method of research has been applied. Data have been 
collected and analyzed based on grounded theory. In an approach towards grounded theory in the research, open, axial, and selective coding methods have been used. Data have been analyzed based on data obtained from field and library studies. The final research pattern has formed three main categories: anticipatory factors, perceptive factors, and care factors. The subcategories and related propositions in the banking industry have also been specified in it. Finally, structural equation modeling and PLS have been used to verify the validity of the model (Heshmati et al., 2019).

Customer experience management is also introduced to have three dimensions, including task-based, mechanical and human-related dimensions. While assessed these dimensions in relation to two variables of trust and loyalty, results showed that all dimensions of customer experience management have a direct relationship with customer trust and loyalty; however, two dependent task-based and human-related variables are of high importance and have to be considered in marketing strategies more than ever (Almasi, 2018). The relationship between customer experience management and customers' mental image was also assessed in the Iranian context. Research shows that customer experience management has a significant effect on customers' mental image in terms of buying decisions (Ghafourian, 2017). Ansari and Sanayei (2016) suggested that while customer loyalty is one of the paths to create competitive advantage, customers are not that loyal to their banks and use electronic services rendered by different banks. They have found that there is a relationship between experience management and continuous use of electronic banking services. According to the results, the following factors are determinants of continuous use of electronic banking services rendered by Mellat Bank: quality of services, loyalty prices, trust, satisfaction, customer expectation, attraction, employees' competence, and ease of usage (Ansari and Sanayei, 2016). Finally, customer experience management and customer loyalty in the hotel management industry have been studied by Derakhshani and Mahmoudi (2013). According to their findings, there is a positive correlation between customer experience management and customer loyalty among customers of four-star hotels. Also, upon the ranking of customer experience management variables from customers' perspective, it was found that the task-based section has the most effect on customers and the human-related and mechanical sections stand next, respectively (Derkhshani and Mahmoudi, 2013).

In short, the literature review in present research shows that many studies have dealt with the importance of customer experience and its management; and, different models in these works of literature have been identified, taking 
steps towards management and providing customers with better experiments. However, considering the gaps existing in the literature related to customer experience management, the following points can be referred to:

1) No research has been conducted through an approach towards grounded theory so that a model in relation to customer experience management be provided. Our goal is to study all five factors in the grounded theory approach and based on the approach presented by Strauss and Corbin (1990) and to extract underlying factors, strategies for practice, outcomes, sequence of stages, and strategies.

2) Studies performed, including that of Kandampully et al. (2018), show that considering organizational basis in providing customer experience management is of high importance. (The present research aims to study customer experience management in the field of information and communications technology that has not been studied yet and this expanding field in the country has to be studied more).

3) Studies performed mainly resulted in abstract models, and customer experience management activities have not been observed in various steps of the customer journey.

All the above three cases are identified gaps in the research literature that form the basis for the present research. In the next step, the research methodology is defined, and the approach to answering such a theoretical gap is specified.

\section{Research Methodology}

Considering the research intends to provide a stepwise model of customer experience management with no direct intention to solve an existing problem in the application and is aimed to contribute to the body of literature, this study is basic research. Research also enjoys a descriptive approach (nonexperimental) where none of the variables studied in the research are modified and/or manipulated. The participants in this study are senior managers of companies from the information and communications technology industry. Participants satisfied the condition of possession of a minimum five-year experience in marketing management. As a minimum of 15 to 20 samples required for grounded theory (Creswell, 2002), 20 members of the population were interviewed using in-depth interviews. Although data saturation was achieved in the 16th interview, the researcher erred on the side of caution and data gathering extended to 20 people. Theoretical sampling has been performed as a sampling approach. Data have been collected through in-depth interviews using interview protocol based on research literature review. The 
validity of interview protocol has been studied through face and content validity from the perspective of 7 academic experts. Inter-coder agreement percentage has been used to evaluate the tool's reliability. In both cases, the technical characteristics of the data collection tool (interview protocol) have been confirmed. The macro-strategy of the research has been grounded theory based on which three coding stages, including open, axial, and selective coding, have been performed for data analysis.

The coding and the modeling were done by the software called ATLAS.ti.The purpose of ATLAS.ti is to help researchers uncover and systematically analyze complex phenomena hidden in unstructured data (text, multimedia, geospatial). The program lets the user locate, code, and annotate findings in primary data material, weigh and evaluate their importance, and visualize the often complex relations between them.

\section{Findings}

As stated in the research methodology section, the data here have been analyzed through three coding approaches (open, axial, and selective). Open preliminary coding has resulted in 377 initial codes. In table 1, the summarized results of open coding are presented.

Table 1

Summarized results of open coding

\begin{tabular}{|c|c|c|c|c|c|c|c|c|c|c|c|c|c|c|c|c|}
\hline \multirow[b]{2}{*}{ Row } & \multirow[b]{2}{*}{ basic open source } & \multicolumn{14}{|c|}{ Interview number } & \\
\hline & & 1 & 23 & 34 & & 67 & 89 & $\begin{array}{l}1 \\
0\end{array}$ & 1 & \begin{tabular}{|l|l|l}
1 & 1 \\
2 & 3
\end{tabular} & \begin{tabular}{l|l}
1 & 1 \\
4 & 5
\end{tabular} & & $\frac{1}{7}$ & & \begin{tabular}{|l|l|}
1 & 20 \\
9 &
\end{tabular} & \\
\hline 1 & Customer needs assessment & 1 & 00 & 00 & & 00 & 00 & 0 & 0 & & \begin{tabular}{l|l}
0 & 1 \\
\end{tabular} & & 0 & & 00 & 2 \\
\hline 2 & Customer segmentation & 1 & 00 & 00 & & 00 & 00 & 00 & & & 00 & & 0 & 0 & 10 & 3 \\
\hline 3 & Specify the customer travel route for each segment & 1 & 00 & 00 & 0 & $\begin{array}{lll}0 & 0 \\
\end{array}$ & 00 & 0 & 0 & 00 & 00 & & 0 & 0 & $\begin{array}{lll}0 & 0 \\
\end{array}$ & 1 \\
\hline 4 & Identify desirable experiences & 1 & 00 & 00 & 0 & 00 & 00 & 0 & 0 & 00 & 00 & 00 & 0 & 0 & \begin{tabular}{|l|l|}
0 & 1 \\
\end{tabular} & 2 \\
\hline 5 & Brand experience design & 1 & 00 & 00 & 0 & 00 & 00 & 0 & 0 & 00 & \begin{tabular}{l|l}
0 & 1 \\
\end{tabular} & 10 & 0 & 0 & $\begin{array}{lll}0 & 0 \\
\end{array}$ & 2 \\
\hline 6 & Create customer contact points & 1 & 00 & 00 & 0 & \begin{tabular}{l|l}
0 & 0 \\
\end{tabular} & \begin{tabular}{l|l}
0 & 1 \\
\end{tabular} & 0 & 0 & 00 & 00 & 00 & 0 & & 00 & 2 \\
\hline 7 & Measurement and development & 1 & 00 & 00 & 0 & 00 & 00 & 1 & 0 & \begin{tabular}{|l|l|l|}
0 & 1 \\
\end{tabular} & 00 & 00 & 0 & 1 & 00 & 4 \\
\hline 8 & CFA Customer Feedback Analysis & 1 & 00 & \begin{tabular}{l|llll}
0 & 1 \\
\end{tabular} & 11 & 00 & 00 & 0 & 0 & & 00 & 00 & 0 & 1 & 00 & 4 \\
\hline 9 & Churn Rates & 1 & 00 & 00 & 0 & 00 & 00 & 0 & 0 & 00 & 10 & 00 & 0 & 0 & \begin{tabular}{l|l|l}
0 & 0 \\
\end{tabular} & 2 \\
\hline 10 & CSAT score- Behavioral & 1 & 00 & 00 & & 00 & \begin{tabular}{l|l}
0 & 1
\end{tabular} & 0 & 0 & 00 & 00 & & 0 & 0 & 10 & 3 \\
\hline 11 & IVR & 1 & 00 & 00 & & 00 & 00 & 0 & 0 & 00 & 00 & 00 & 0 & 0 & 10 & 3 \\
\hline 12 & $\begin{array}{l}\text { NPS - Expressing willingness to refer social network } \\
\text { members }\end{array}$ & 1 & 00 & 00 & & 0 & 00 & 0 & 0 & & 0 & & 0 & 0 & & 2 \\
\hline 13 & VOC & 0 & 10 & 00 & & 00 & 00 & 0 & 0 & 10 & 00 & 00 & 0 & 0 & \begin{tabular}{l|l}
0 & 0
\end{tabular} & 3 \\
\hline 14 & Tools & 0 & 00 & 00 & & 00 & 00 & 0 & 0 & & $0 \mid \begin{array}{lll}0 & 1 & r\end{array}$ & & 0 & 0 & 00 & 1 \\
\hline 15 & Customer experience measurement tools & 0 & 00 & 00 & & 10 & 00 & 0 & & & 010 & & 0 & 0 & 00 & 3 \\
\hline 16 & App Store & 1 & 00 & 00 & & $\begin{array}{lll}0 & 0\end{array}$ & 00 & 0 & 0 & \begin{tabular}{l|lll}
0 & 1
\end{tabular} & 010 & & 0 & & \begin{tabular}{l|l}
0 & 0
\end{tabular} & 3 \\
\hline 17 & Effectiveness of customer experience & 0 & 010 & 00 & & 00 & 00 & 0 & 0 & & 00 & & 0 & 0 & 00 & 0 \\
\hline 18 & Feeling expressed & 0 & 00 & 01 & & 00 & 00 & 0 & 0 & & 0 & & 0 & & \begin{tabular}{|l|l|}
0 & 1 \\
\end{tabular} & 2 \\
\hline 19 & Customer feeling & 0 & 00 & \begin{tabular}{l|l|l|l|l|l|l|l}
0 & 1 \\
\end{tabular} & & $\begin{array}{lll}0 & 0\end{array}$ & \begin{tabular}{l|l}
0 & 1
\end{tabular} & 0 & & & $0 \mathrm{c}$ & & 1 & & \begin{tabular}{l|l}
1 & 1 \\
\end{tabular} & 5 \\
\hline 20 & brand value & 0 & 00 & 00 & & \begin{tabular}{l|l}
0 & 0 \\
\end{tabular} & \begin{tabular}{l|l}
0 & 1 \\
\end{tabular} & 0 & & & 0 & & 0 & & \begin{tabular}{l|l}
0 & 0 \\
\end{tabular} & \\
\hline
\end{tabular}




\begin{tabular}{|c|c|c|c|c|c|c|c|c|c|c|c|c|c|c|c|c|}
\hline \multirow[b]{2}{*}{ Row } & \multirow[b]{2}{*}{ basic open source } & \multicolumn{14}{|c|}{ Interview number } & \\
\hline & & 1 & 23 & & & 6 & & & $\begin{array}{l}1 \\
0\end{array}$ & & \begin{tabular}{l|l|l|l|}
1 & 1 \\
2 & 3 & \\
\end{tabular} & \begin{tabular}{|l|l|l|l}
1 & 1 \\
4 & 5 & 5 \\
\end{tabular} & & \begin{tabular}{|l|l|l|l|l|} 
& 1 \\
7 & 8 \\
\end{tabular} & 92 & \\
\hline 365 & Targeting the customer experience & 0 & 00 & 0 & 0 & 1 & 00 & & 0 & 0 & 00 & 00 & & 000 & 00 & 1 \\
\hline 366 & Customer payment fee & 0 & 00 & 0 & 0 & 1 & 00 & 0 & 0 & 0 & \begin{tabular}{ll|}
0 & 0 \\
\end{tabular} & 00 & & 000 & 00 & 1 \\
\hline 367 & Time cost & 0 & 00 & 0 & 0 & 1 & 00 & & 00 & 0 & 100 & 00 & & 000 & \begin{tabular}{l|l}
0 & 1 \\
\end{tabular} & 3 \\
\hline 368 & Financial cost & 0 & 00 & 0 & 0 & 1 & 00 & & 0 & 0 & 100 & 00 & & \begin{tabular}{l|l|l|l|} 
& 0 & \\
\end{tabular} & 00 & 2 \\
\hline 369 & $\begin{array}{l}\text { Coordinating elements of the customer experience in the } \\
\text { company }\end{array}$ & 0 & 00 & 0 & 0 & 0 & 0 & & 0 & & 00 & 00 & & 00 & 00 & 0 \\
\hline 370 & Brand alignment & 0 & 00 & & & 0 & 00 & & 0 & & 10 & 00 & & 000 & 00 & 1 \\
\hline 371 & Epidemic & 0 & 00 & 1 & 0 & 0 & 00 & & 0 & & \begin{tabular}{l|l|}
1 & 1 \\
\end{tabular} & 00 & & 000 & 00 & 3 \\
\hline 372 & Brand identity & 0 & 00 & 0 & 0 & 0 & 00 & 0 & 0 & 0 & \begin{tabular}{l|l|}
0 & 1 \\
\end{tabular} & 00 & & 00 & 00 & 1 \\
\hline 373 & Customer excitement & 0 & 00 & & 0 & 0 & 00 & & 0 & & \begin{tabular}{l|l|}
0 & 0 \\
\end{tabular} & 00 & & 000 & 00 & 2 \\
\hline 374 & Web chat & 1 & 00 & 0 & 0 & 0 & \begin{tabular}{l|lll}
0 & 1 &
\end{tabular} & 0 & 0 & 0 & $0 \quad 0$ & 00 & 1 & 000 & 00 & 3 \\
\hline 375 & Website & 1 & 00 & & 0 & 0 & \begin{tabular}{l|lll}
0 & 1 &
\end{tabular} & 1 & 0 & 0 & 00 & 00 & & 000 & 00 & 4 \\
\hline 376 & Customer loyalty & 0 & 10 & & 1 & 0 & 00 & 1 & 0 & 0 & \begin{tabular}{ll|} 
& 0 \\
\end{tabular} & 00 & & 00 & \begin{tabular}{|l|l|l}
0 & 1 \\
\end{tabular} & 5 \\
\hline 377 & Integration of distribution channels & 1 & 00 & & & 0 & 00 & & 0 & & \begin{tabular}{l|l|}
0 & 0 \\
\end{tabular} & $0 \quad 0$ & & \begin{tabular}{l|l|l|l|l|} 
& 0 & \\
\end{tabular} & 00 & 1 \\
\hline To & & 158 & 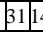 & 45 & & 47 & 112 & & 436 & & \begin{tabular}{l|l|}
5722 \\
\end{tabular} & 337 & & \begin{tabular}{l|l|l|l|}
4 & 17 \\
\end{tabular} & & \begin{tabular}{l|l|}
5 & 869 \\
\end{tabular} \\
\hline
\end{tabular}

Source: Research Findings

The preliminary open coding performed resulted in 377 initial codes in terms of 869 open coding activities. However, an accurate study of these cases shows that most of them have semantic overlaps, different phrases form, i.e., similar codes. So, in the next steps, these codes were merged, and the final result of open coding was 265 open codes. The second step in grounded theory analyses is axial coding. That is, understanding concepts based on dynamic relationships between them. These concepts have to provide the required basis for the creation of the theory. Axial coding is focused on creating a model that specifies, in detail, certain conditions that create the phenomenon. Based on the theory of Strauss-Corbin (1990), axial coding is aimed at recombination of those data that have been separated during open coding (Moghaddam, 2006). Table 2 shows the axial coding steps to data analysis.

Table 2

Summarized results of axial coding

\begin{tabular}{|c|c|c|}
\hline $\begin{array}{l}\text { Item } \\
\text { No. in } \\
\text { the list } \\
\text { of open } \\
\text { codes }\end{array}$ & Axial codes & Sample of open codes \\
\hline 1 & \multirow{5}{*}{$\begin{array}{l}\text { Dimensions of customer } \\
\text { experience }\end{array}$} & Customer feelings \\
\hline 2 & & Expressed feelings \\
\hline 3 & & Feelings not expressed \\
\hline 4 & & Establishing a personal relationship with the customer \\
\hline 5 & & Customer ideal experience \\
\hline 31 & \multirow{3}{*}{$\begin{array}{l}\text { Executive prerequisites of } \\
\text { customer experience management }\end{array}$} & Corporate strategy \\
\hline 32 & & Employees' motivation \\
\hline 33 & & Making pattern of international examples \\
\hline
\end{tabular}




\begin{tabular}{|c|c|c|}
\hline 34 & & $\begin{array}{l}\text { Believing in the role played by customer experience in } \\
\text { organization }\end{array}$ \\
\hline 35 & & Organizational plan of improving customer experience \\
\hline 66 & \multirow{5}{*}{ Step 1- awareness } & Customer needs assessment \\
\hline 67 & & Customer segmentation \\
\hline 68 & & Creating customer touchpoints \\
\hline 69 & & Quality of information \\
\hline 70 & & Useful information \\
\hline 93 & \multirow{5}{*}{ Step 2- paying attention } & Brand values in customer experience \\
\hline 94 & & Sales promotion \\
\hline 95 & & Joining customer in touchpoints \\
\hline 96 & & Linking experience-brand in customer's mind \\
\hline 97 & & Brand experience \\
\hline 107 & \multirow{5}{*}{ Step 3- evaluation } & Packaging \\
\hline 108 & & Packages and recommendations \\
\hline 109 & & Network coverage \\
\hline 110 & & Sales arrangements \\
\hline 111 & & Translating product to customer experience \\
\hline 124 & \multirow{4}{*}{ Step 4- deciding to buy } & Reviewing accuracy of invoice \\
\hline 125 & & Supplying touchpoints \\
\hline 126 & & Preliminary purchase \\
\hline 127 & & Channel to order through \\
\hline 133 & \multirow{5}{*}{ Step 5-purchasing } & Online ordering \\
\hline 134 & & Payment \\
\hline 135 & & Leveraging new channels \\
\hline 136 & & Creating organizational commitment to customer \\
\hline 137 & & Awarding against waiting time \\
\hline 158 & \multirow{5}{*}{ Step 6- using } & Customer's tendency towards repeating the experience \\
\hline 159 & & Maintaining customer positive experience \\
\hline 160 & & Involving customer \\
\hline 161 & & Enough time to experience product \\
\hline 162 & & Ease of usage \\
\hline 169 & \multirow{5}{*}{$\begin{array}{l}\text { Step 7- repeated purchase/ } \\
\text { complaint }\end{array}$} & Identifying desirable experiences \\
\hline 170 & & Customer feedback analysis \\
\hline 171 & & Customer experience management effectiveness \\
\hline 172 & & Modifying action based on exception \\
\hline 173 & & Churn rates-behavioral \\
\hline 189 & \multirow{5}{*}{ Step 8- loyalty/opposition } & Trust \\
\hline 190 & & Sharing experiments \\
\hline 191 & & Sharing negative experiments with friends \\
\hline 192 & & Sharing negative experiments with colleagues \\
\hline 193 & & Sharing negative experiments in social media \\
\hline 201 & \multirow{3}{*}{ Step 9- advocacy } & Sharing experience \\
\hline 202 & & Customer support \\
\hline 203 & & Special attention paid to high-value customers (HVC) \\
\hline 204 & \multirow{5}{*}{$\begin{array}{l}\text { Customer experience measurement } \\
\text { and analysis }\end{array}$} & CSAT score \\
\hline 205 & & IVR \\
\hline 206 & & VOC \\
\hline 207 & & Evaluating financial return of journey \\
\hline 208 & & Measuring customer expectations \\
\hline 257 & Background & Size of company \\
\hline
\end{tabular}




\begin{tabular}{|c|c|c|}
\hline 258 & & Social chaos \\
\hline 259 & & Accepting results of the survey by customer \\
\hline 260 & & Company's experience \\
\hline 261 & & Managers' experiences \\
\hline 288 & \multirow{5}{*}{$\begin{array}{l}\text { Outcomes of customer experience } \\
\text { management }\end{array}$} & Brand value \\
\hline 289 & & Feedback \\
\hline 290 & & Maturity of customer experience management system \\
\hline 291 & & Improvement of customer experience \\
\hline 292 & & Satisfying customers' requirements and goals \\
\hline
\end{tabular}

Source: Research Findings

Selective coding takes place as the last stage of the analysis. It is a process through which the identified classes have been connected to the axial class, and the final basis for the grounded theory is provided (Babchuk, 1996). Table 3 shows a summary of selective coding results:

Table 3

Summary of selective coding results

\begin{tabular}{|c|c|c|c|c|c|}
\hline \multirow[t]{2}{*}{$\begin{array}{l}\text { Item } \\
\text { No. }\end{array}$} & \multirow[t]{2}{*}{ Axial codes } & \multirow[t]{2}{*}{ Selective structures } & \multirow[t]{2}{*}{ Sample of open code } & \multicolumn{2}{|c|}{$\begin{array}{c}\text { Active } \\
\text { actor/stakeholder }\end{array}$} \\
\hline & & & & Customer & Company \\
\hline 1 & \multirow{6}{*}{$\begin{array}{l}\text { Dimensions of } \\
\text { customer } \\
\text { experience }\end{array}$} & \multirow{2}{*}{ Feelings } & Expressed feelings & 1 & 0 \\
\hline 2 & & & Feelings not expressed & 1 & 0 \\
\hline 7 & & \multirow{2}{*}{ Excitement } & Fatigue & 1 & 0 \\
\hline 8 & & & Anger & 1 & 0 \\
\hline 11 & & \multirow{2}{*}{ Experimental features } & $\begin{array}{l}\text { Experiencing } \\
\text { prepayment }\end{array}$ & 1 & 0 \\
\hline 12 & & & $\begin{array}{l}\text { Experience specific to } \\
\text { each service }\end{array}$ & 1 & 0 \\
\hline 19 & \multirow{7}{*}{$\begin{array}{l}\text { Executive } \\
\text { prerequisites of } \\
\text { customer } \\
\text { experience } \\
\text { management }\end{array}$} & \multirow[b]{2}{*}{ Strategic prerequisites } & Corporate strategy & 0 & 1 \\
\hline 20 & & & $\begin{array}{l}\text { Believing the role } \\
\text { played by customer } \\
\text { experience } \\
\text { management in the } \\
\text { organization }\end{array}$ & 0 & 1 \\
\hline 30 & & \multirow[b]{2}{*}{ Human prerequisites } & Employees' motivation & 0 & 1 \\
\hline 31 & & & $\begin{array}{l}\text { Encouraging active } \\
\text { forces in customer } \\
\text { experience } \\
\text { management }\end{array}$ & 0 & 1 \\
\hline 35 & & \multirow{3}{*}{ Technical prerequisites } & Supplying equipment & 0 & 1 \\
\hline 36 & & & $\begin{array}{l}\text { Taking pattern of } \\
\text { international examples }\end{array}$ & 0 & 1 \\
\hline 37 & & & $\begin{array}{l}\text { Predicting future needs } \\
\text { of customer }\end{array}$ & 0 & 1 \\
\hline 49 & \multirow{3}{*}{$\begin{array}{l}\text { Step 1- } \\
\text { awareness }\end{array}$} & \multirow{3}{*}{\begin{tabular}{|l|l|} 
Information & $\begin{array}{l}\text { Quality } \\
\text { of } \\
\text { dimension }\end{array}$ \\
informa \\
tion
\end{tabular}} & Useful information & 0 & 1 \\
\hline 50 & & & Learned information & 0 & 1 \\
\hline 51 & & & Email & 0 & 1 \\
\hline
\end{tabular}




\begin{tabular}{|c|c|c|c|c|c|}
\hline 52 & & & Instagram & 0 & 1 \\
\hline 53 & & interface & Word of mouth & 1 & 0 \\
\hline 62 & & Spatial-temporal & $\begin{array}{l}\text { first moment of truth } \\
\text { (MOT) }\end{array}$ & 0 & 1 \\
\hline 63 & & dimension & $\begin{array}{l}\text { Prevalence of numbers } \\
\text { of stores }\end{array}$ & 0 & 1 \\
\hline 66 & & & Customer segmentation & 0 & 1 \\
\hline 67 & & Confrontation dimension & $\begin{array}{|ll|}\begin{array}{l}\text { Creating } \\
\text { touchpoint }\end{array} & \text { customer } \\
\end{array}$ & 0 & 1 \\
\hline 72 & \multirow{4}{*}{\multicolumn{2}{|c|}{ Step 2-paying attention }} & $\begin{array}{l}\text { Brand values in } \\
\text { customer experience }\end{array}$ & 0 & 1 \\
\hline 73 & & & Sales promotion & 0 & 1 \\
\hline 74 & & & \begin{tabular}{|ll}
$\begin{array}{l}\text { Joining customer at } \\
\text { touchpoint }\end{array}$ & at \\
\end{tabular} & 0 & 1 \\
\hline 75 & & & $\begin{array}{l}\text { Linking experience- } \\
\text { brand in customer's } \\
\text { mind }\end{array}$ & 1 & 0 \\
\hline 86 & \multirow{8}{*}{$\begin{array}{l}\text { Step 3- } \\
\text { evaluation }\end{array}$} & \multirow{5}{*}{ Characteristics of service } & Packaging & 0 & 1 \\
\hline 87 & & & \begin{tabular}{|ll} 
Packages & and \\
recommendations
\end{tabular} & 0 & 1 \\
\hline 88 & & & Network coverage & 0 & 1 \\
\hline 89 & & & \begin{tabular}{|l|} 
Translating product to \\
customer experience
\end{tabular} & 0 & 1 \\
\hline 90 & & & Concepts of privacy & 0 & 1 \\
\hline 95 & & \multirow{3}{*}{$\begin{array}{l}\text { Service rendering } \\
\text { arrangements }\end{array}$} & Sales arrangements & 0 & 1 \\
\hline 96 & & & $\begin{array}{l}\text { Numbers of selection } \\
\text { rights of customer }\end{array}$ & 0 & 1 \\
\hline 97 & & & \begin{tabular}{|l}
$\begin{array}{l}\text { Optimization } \\
\text { number of options }\end{array}$ \\
\end{tabular} & 0 & 1 \\
\hline 102 & \multirow{3}{*}{\multicolumn{2}{|c|}{ Step 4- making decision to buy }} & $\begin{array}{l}\text { Reviewing accuracy of } \\
\text { invoice }\end{array}$ & 1 & 0 \\
\hline 103 & & & Supplying touchpoints & 0 & 1 \\
\hline 104 & & & Preliminary purchase & 1 & 0 \\
\hline 111 & \multirow{6}{*}{ Step 5-purchase } & \multirow{2}{*}{ Purchase events } & Online ordering & 1 & 0 \\
\hline 112 & & & Payment & 1 & 0 \\
\hline 120 & & \multirow{2}{*}{ Purchase point } & Kiosk & 0 & 1 \\
\hline 121 & & & Website & 0 & 1 \\
\hline 122 & & \multirow[b]{2}{*}{ Method of purchase } & Self service & 0 & 1 \\
\hline 123 & & & $\begin{array}{|ll|}\begin{array}{l}\text { Leveraging } \\
\text { channels }\end{array} & \text { new } \\
\end{array}$ & 0 & 1 \\
\hline 130 & \multirow{4}{*}{ Step 6- usage } & \multirow{2}{*}{ Delivery } & $\begin{array}{l}\text { Web-based distribution } \\
\text { channels }\end{array}$ & 0 & 1 \\
\hline 131 & & & $\begin{array}{l}\text { Integrating distribution } \\
\text { channels }\end{array}$ & 0 & 1 \\
\hline 134 & & \multirow[t]{2}{*}{ Usage } & $\begin{array}{l}\text { Explanations provided } \\
\text { with product }\end{array}$ & 0 & 1 \\
\hline 135 & & & Activating order & 0 & 1 \\
\hline 141 & \multirow{3}{*}{$\begin{array}{l}\text { Step 7- purchase } \\
\text { output }\end{array}$} & \multirow{3}{*}{ Repeated purchase } & $\begin{array}{|ll|}\begin{array}{l}\text { Identifying } \\
\text { experiments }\end{array} & \text { desirable } \\
\end{array}$ & 0 & 1 \\
\hline 142 & & & $\begin{array}{l}\text { Making obstacles on } \\
\text { customer's exit }\end{array}$ & 0 & 1 \\
\hline 143 & & & NPS- tendency towards & 1 & 0 \\
\hline
\end{tabular}




\begin{tabular}{|c|c|c|c|c|c|}
\hline & & & $\begin{array}{l}\text { referring social } \\
\text { network members }\end{array}$ & & \\
\hline 150 & & \multirow{2}{*}{ Complaint } & $\begin{array}{l}\text { Modification action } \\
\text { based on exception }\end{array}$ & 0 & 1 \\
\hline 151 & & & $\begin{array}{l}\text { Churn rates- complaint } \\
\text { rate }\end{array}$ & 1 & 0 \\
\hline 156 & & \multirow[t]{2}{*}{ Lack of reaction } & \begin{tabular}{|lr}
$\begin{array}{l}\text { Reviewing } \\
\text { from }\end{array}$ & $\begin{array}{r}\text { experience } \\
\text { customer }\end{array}$ \\
perspective & \\
\end{tabular} & 0 & 1 \\
\hline 157 & & & $\begin{array}{l}\text { Time taken for call } \\
\text { center to answer }\end{array}$ & 0 & 1 \\
\hline 158 & \multirow{6}{*}{$\begin{array}{l}\text { Step 8- } \\
\text { loyalt/confrontat } \\
\text { ion }\end{array}$} & \multirow{3}{*}{$\begin{array}{l}\text { Customer experience } \\
\text { clusters }\end{array}$} & Loyalty cluster & 1 & 0 \\
\hline 159 & & & $\begin{array}{l}\begin{array}{l}\text { Recommendation } \\
\text { cluster }\end{array} \\
\end{array}$ & 1 & 0 \\
\hline 160 & & & Attention cluster & 1 & 0 \\
\hline 162 & & Trust & Trust & 1 & 0 \\
\hline 163 & & \multirow[b]{2}{*}{ Satisfaction } & Sharing experience & 1 & 0 \\
\hline 164 & & & \begin{tabular}{|lr}
$\begin{array}{l}\text { Sharing } \\
\text { experiments }\end{array}$ & negative \\
friends & with \\
\end{tabular} & 1 & 0 \\
\hline 168 & \multirow{3}{*}{\multicolumn{2}{|c|}{ Step 9- advocacy }} & Sharing experiments & 1 & 0 \\
\hline 169 & & & Customer support & 0 & 1 \\
\hline 170 & & & $\begin{array}{l}\text { Especial attention paid } \\
\text { to HVC }\end{array}$ & 0 & 1 \\
\hline 171 & \multirow{16}{*}{$\begin{array}{l}\text { Measurement } \\
\text { and analyzing } \\
\text { customer } \\
\text { experience }\end{array}$} & \multirow{5}{*}{ Data collection } & CSAT score & 0 & 1 \\
\hline 172 & & & IVR & 0 & 1 \\
\hline 173 & & & VOC & 0 & 1 \\
\hline 174 & & & Questioning & 0 & 1 \\
\hline 188 & & & $\begin{array}{|lr|}\text { Data } & \text { collection } \\
\text { regarding } & \text { brand } \\
\text { perception } & \\
\end{array}$ & 0 & 1 \\
\hline 189 & & \multirow{3}{*}{ Data recording } & Recording feedback & 0 & 1 \\
\hline 190 & & & \begin{tabular}{|l|} 
Documenting \\
feedbacks
\end{tabular} & 0 & 1 \\
\hline 191 & & & $\begin{array}{l}\text { Analyzing changing } \\
\text { procedure of customer } \\
\text { feedback }\end{array}$ & 0 & 1 \\
\hline 192 & & \multirow{3}{*}{ Data analysis } & Analyzing social media & 0 & 1 \\
\hline 193 & & & $\begin{array}{|ll|}\begin{array}{l}\text { Analyzing } \\
\text { journey }\end{array} & \text { customer } \\
\end{array}$ & 0 & 1 \\
\hline 194 & & & \begin{tabular}{|ll}
$\begin{array}{l}\text { Analyzing } \\
\text { complaint }\end{array}$ & customer \\
\end{tabular} & 0 & 1 \\
\hline 200 & & \multirow[t]{3}{*}{ Interpreting the findings } & $\begin{array}{lrr}\text { Comparing } & \text { real } \\
\text { customer } & \text { experience } \\
\text { and organizational } \\
\text { perception of his } \\
\text { experience }\end{array}$ & 0 & 1 \\
\hline 201 & & & Identifying HVC & 0 & 1 \\
\hline 202 & & & \begin{tabular}{|l} 
Satisfaction \\
measurement
\end{tabular} & 0 & 1 \\
\hline 208 & & \multirow{2}{*}{$\begin{array}{l}\text { Monitoring performance } \\
\text { of customer experience }\end{array}$} & Seasonal reporting & 0 & 1 \\
\hline 209 & & & Continuous reporting & 0 & 1 \\
\hline
\end{tabular}




\begin{tabular}{|c|c|c|c|c|c|}
\hline 210 & \multirow{21}{*}{ Background } & \multirow{3}{*}{$\begin{array}{l}\text { Organizational } \\
\text { background }\end{array}$} & Size of company & 0 & 1 \\
\hline 211 & & & Company experience & 0 & 1 \\
\hline 212 & & & Managers' experiments & 0 & 1 \\
\hline 219 & & \multirow{3}{*}{ Market background } & $\begin{array}{l}\text { Degree of market } \\
\text { competitiveness }\end{array}$ & 0 & 1 \\
\hline 220 & & & \begin{tabular}{|l|} 
International \\
competition
\end{tabular} & 0 & 0 \\
\hline 221 & & & Level of usage & 0 & 0 \\
\hline 222 & & \multirow{3}{*}{ Technological background } & Internet speed & 0 & 0 \\
\hline 223 & & & $\begin{array}{l}\text { Performance of mobile } \\
\text { band }\end{array}$ & 0 & 0 \\
\hline 224 & & & \begin{tabular}{|l|} 
Accessibility to \\
technology
\end{tabular} & 0 & 1 \\
\hline 225 & & \multirow{4}{*}{ Social background } & Social chaos & 0 & 0 \\
\hline 226 & & & $\begin{array}{l}\text { Level of public } \\
\text { satisfaction in society }\end{array}$ & 0 & 0 \\
\hline 227 & & & $\begin{array}{l}\text { Culture of answering } \\
\text { surveys }\end{array}$ & 0 & 0 \\
\hline 228 & & & \begin{tabular}{|lll}
$\begin{array}{l}\text { Public } \\
\text { society }\end{array}$ & culture in \\
\end{tabular} & 0 & 0 \\
\hline 232 & & \multirow{4}{*}{$\begin{array}{l}\text { Legal-political } \\
\text { background }\end{array}$} & $\begin{array}{l}\text { Political pressures on } \\
\text { company }\end{array}$ & 0 & 0 \\
\hline 233 & & & Regulatory regulations & 0 & 0 \\
\hline 234 & & & Sanctions & 0 & 0 \\
\hline 235 & & & $\begin{array}{l}\text { Accessibility to the } \\
\text { global payment system }\end{array}$ & 0 & 1 \\
\hline 236 & & \multirow{2}{*}{ Economic background } & Currency rate & 0 & 0 \\
\hline 237 & & & Customer's income & 1 & 0 \\
\hline 238 & & \multirow[b]{2}{*}{ Natural background } & Outbreak & 0 & 0 \\
\hline 239 & & & $\begin{array}{l}\text { Geographical status of } \\
\text { customers }\end{array}$ & 1 & 0 \\
\hline 240 & \multirow{12}{*}{$\begin{array}{l}\text { Outcomes of } \\
\text { customer } \\
\text { experience } \\
\text { management }\end{array}$} & \multirow{2}{*}{ Financial performance } & Income growth & 0 & 1 \\
\hline 241 & & & Profitability & 0 & 1 \\
\hline 242 & & \multirow{3}{*}{$\begin{array}{l}\text { Market and customer } \\
\text { performance }\end{array}$} & Increasing market share & 0 & 1 \\
\hline 243 & & & Brand value & 0 & 1 \\
\hline 244 & & & $\begin{array}{l}\text { Improvement of } \\
\text { customer experience }\end{array}$ & 0 & 1 \\
\hline 258 & & \multirow{3}{*}{ Internal processes } & Reducing waiting time & 0 & 1 \\
\hline 259 & & & $\begin{array}{l}\text { Maturity of customer } \\
\text { experience } \\
\text { management system }\end{array}$ & 0 & 1 \\
\hline 260 & & & $\begin{array}{l}\begin{array}{l}\text { Rendering service to } \\
\text { customer }\end{array} \\
\end{array}$ & 0 & 1 \\
\hline 261 & & \multirow{4}{*}{ Growth and learning } & Feedback & 0 & 1 \\
\hline 262 & & & $\begin{array}{l}\text { Accessibility of } \\
\text { organization's members } \\
\text { to results of customer } \\
\text { experience evaluation }\end{array}$ & 0 & 1 \\
\hline 263 & & & \begin{tabular}{|ll} 
Identifying & weakness \\
points in & customer \\
experience & \\
\end{tabular} & 0 & 1 \\
\hline 264 & & & Identifying important & $0-$ & 1 \\
\hline
\end{tabular}




\begin{tabular}{|l|l|l|l|l|}
\hline 265 & & journeys & & \\
\cline { 3 - 5 } & & Change of attitudes & 0 & 1 \\
\hline
\end{tabular}

Source: Research Findings

The model is modified and limited to dimensions of customer experience management at the second stage of selective coding and with the extraction of active fields of customer experience management from indices of customer activity. The final extraction model from grounded theory is provided for customer experience management in the diagram provided below.

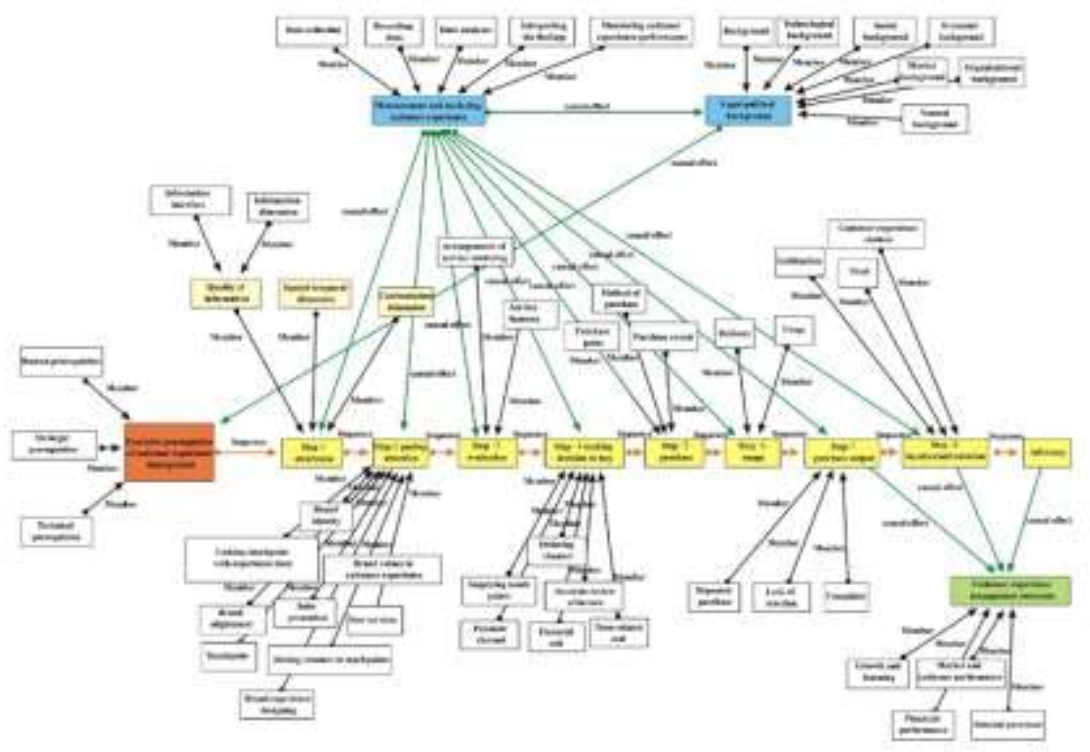

Figure 1. Step making model of customer experience management.

\section{Discussion, Conclusion and Recommendations}

The present study provided a stepwise model of customer experience management. Adopting a grounded theory approach resulted in identifying dimensions of customer experience management during customer journey; however, together with the dimensions of customer experience, its 
prerequisites, concepts related to measurement of customer experiments, contextual factors, and outcomes of customer experience management identified.

In sum, Customer experience management requires the realization of executive prerequisites included in three principles: strategic prerequisites, human-related prerequisites, and technical prerequisites. The status of strategic prerequisites can be found in the research literature. This finding can be associated with the existing literature. According to Rahimi et al. (2019), causal factors effective on the perception and expectations of the customer regarding services and the one who renders them will provide multiple value creation strategies to the customer, and the outcomes of such value creation will determine the loyalty level (Rahimi et al., 2019). A few references have been made to human and technical strategies (Derakhshani \& Mahmoudi, 2013) in the research literature. Still, the present study has successfully identified its sub-dimensions (Tables 2 and 3).

- Findings of the present study show that capable human resources are considered prerequisites of customer experience management realization; so, it is recommended that organizations employ or educate skilled human resources in this field, so that customer experience management becomes possible.

- According to the findings, the realization of customer experience management requires determining its strategies; so, it is recommended that customer experience plan and set as a goal at the top of the organizational hierarchy as a basic concept.

Findings of the present study show that capable human resources are considered as prerequisites of customer experience management realization; so, it is recommended that technical aspects of the organization be updated so that efficient customer experience management will become possible and its positive outcomes will be used, considering high importance of technical understructure in customer experience management.

The concept of customer experience has three dimensions of feelings (expressed and not expressed, etc.), excitement (happiness, anger, fatigue, etc.), and experimental features (prepayment experience, special experience regarding service, etc.), and its sub-dimensions have also been identified. The sensational and experimental dimensions of experience have had traces in previous studies. For example, as Olenius (2013) stated, experience is sensational and unconscious and can either create value or destroy it. Identifying the point that which elements of physical experience of a person is affected by these feelings can define the experimental gap i.e. the difference 
between what we do and what people are really in need of is very vital (Olenius, 2013).

- Considering the point that, in this study, measuring customer experience has been identified as a basic activity through steps taken in customer experience management. Activities related to data collection, recording, analyzing, interpreting, and monitoring related to customer experience are recommended to be performed by the organizational knowledge management system as continuous activities.

We identified nine steps of customer experience management as awareness, attention, evaluation, decision to buy, purchasing, usage, purchase output, loyalty/confrontation, and advocacy. According to our findings, awareness includes information, Spatio-temporal, and confrontation dimension with their sub-dimensions. Attention includes such concepts as brand values in customer experience. The evaluation step in the customer journey includes two groups of customer experience management factors, i.e., service features and arrangements of rendering service. Purchasing decision includes activities like an accurate review of the invoice, supplying touchpoints. There have been customer experience management activities in step five, supervising purchase events, purchase points, purchase method, and similar factors with more sub-components. In the sixth step of the customer journey (usage), delivery and usage play their parts. The output of the stage has resulted in step 7 of the customer journey i.e., purchase outputs. In this step, customer experience management has to do with desirable outputs like repeated purchase and undesirable outputs such as complaint and/or lack of reaction. In step eight of customer journey, customer experience management appears in two events including loyalty or confrontation. In this step, customer experience clusters are formed (advocacy, recommendation, attention cluster, etc.) that are based on trust and satisfaction. Under desirable conditions, the ninth step of customer journey is advocacy. In research literature, such separation for customer experience management is not found through the steps taken in customer journey and therefore, this part of findings will remove the theoretical gap discussed in literature review.

In addition to the findings mentioned above, customer experience management requires measurement and evaluation activities, including data collection, data recording, and data analysis, interpreting findings, and monitoring customer experience performance. The importance of data collection and analysis and using them in the customer experience management process has been well-referred to in research literature (Meyer and Schwager, 2007; Homburg et al., 2017). 
Despite being ignored in previous studies, the present research findings also resulted in identifying background factors in customer experience management, including organizational background, market background, technological background, social background, legal-political background, economic background, and natural background. The Sub-dimensions of the underlying factors have been identified along with the components related to each dimension (tables 2 and 3 ).

- Considering the point that, in this study, measuring customer experience has been identified as a basic activity through steps taken in customer experience management. Activities related to data collection, recording, analyzing, interpreting, and monitoring related to customer experience are recommended to be performed by the organizational knowledge management system as continuous activities.

Finally, the findings have identified customer experience management outcomes through steps taken in the customer journey. From the perspective of the present research, customer experience management can result in the occurrence of practical outcomes, including financial performance, market and customer, internal processes, and growth and learning for the organization. The outputs of customer experience management are among the most obvious concepts ignored in available studies. In other words, by specifying these outputs, those questions asked regarding the existential philosophy of implementing customer experience management have become answerable.

- Considering the findings resulted from data extracted from an organization with a service rendering nature, it is recommended for future studies to evaluate how these findings can be generalized in relation to production organizations.

- Based on the model obtained from the present study, future studies are recommended to review how probable the development of quantitative tools is to measure customer experience through steps taken in the customer journey. 


\section{References}

Almasi, K. (2018), "Evaluating Customer Experience Management in Relation to Home Appliances Industry", Research Center for Development Studies, ACECR and Azad Negareh Institute of Higher Education, 1, 11.

Ansari, A., \& Sanayei, A (2016), "Customer Experience Management and Continuous Usage Made of Bank Electronic Services by Customers", Strategic Management Studies, Vol.7, 65-87.

Babchuk, W. A. (1996). Glaser or Strauss? Grounded Theory and Adult Education. Paper Presented at the Proceedings of the 15th Annual Midwest Research-toPractice Conference in Adult, Continuing, and Community Education.

Capgemini, (2017). Banking trends_2017_web_version.pdf. [online] Available at: [Accessed 20 Jan. 2018]

Creswell, J. W. (2002). Educational Research: Planning, Conducting, and Evaluating Quantitative: Prentice Hall Upper Saddle River, NJ.

Derakhshani, O. \& Mahmoudi, O. (2013). Studying the Relationship between Customer Experience Management (CEM) and Customer Loyalty in Hotel Management Industry, Tourism (University of Science and Culture), (2013)2. //:Retrieved from Http//ensani.ir/fa/article/335870

Forrester. (2017). Improving CX through Business Discipline Drives Growth. Retrieved from https://www.forrester.com/report /Improving $+\mathrm{CX}+$ Through + Business + Discipline+Drives $+\mathrm{G} \quad$ rowth/-/ERES137906

Gartner (2017). Top 10 Strategic Technology Trends for 2018. Retrieved fromhttps://goo.gl/Emkt37, Accessed date: 14 January 2018.

Gartner (2018). 3 Reasons Why VR and AR are Slow to Take off. Retrieved from: https://www.gartner.com/smarterwithgartner/ 3-reasons-why-vr-and-ar-areslow-to-take-off/.

Ghafourian, M. (2017). Effect of Customer Experience Management on Customer Mental Image in Buying Automotive Products Manufactured in China (Case Study: Modiran Khodro Co.), Islamic Azad University, Naragh Branch, M.A. Thesis

Hakimi, H., Divandari, A., Keimasi, M., \& Haghighi Kaffash, M. (2019). Providing Formation Model of Customer Experience in Retail Banking Through Those Factors Managed by Organization Through an Approach Towards Explanatory Structural Modeling, Journal of Commercial Management, 11(3), 565-584. Doi:10.22059/Jibm.267812.3285.2019

Heshmati, E., Saiedian, H. \& Zadeh, B. (2019), Designing Customer Experience Management Model in Bank Services, Commercial Management Explorations, 11(21), 247-268

Homburg, C., Jozić, D., \& Kuehnl, C. (2017). Customer Experience Eanagement: Toward Implementing an Evolving Marketing Concept. Journal of the Academy of Marketing Science, 45(3), 377-401. 
Hwang, J., \& Seo, S. (2016). A Critical Review of Research on Customer Experience Management: Theoretical, Methodological and Cultural Perspectives. International Journal of Contemporary Hospitality Management, 28(10), 22182246 .

Kandampully, J., \& Solnet, D. (2015). Service Management Principles: For hospitality and tourism. International Journal of Contemporary Hospitality Management Customer experience management in hospitality: a literature synthesis, new understanding, and research agenda

Kandampully, J., Zhang, T. C., \& Jaakkola, E. (2018). Customer Experience Management in Hospitality. International Journal of Contemporary Hospitality Management, DOI: 10.1108/IJCHM-10-2015-0549.

Klink, R. R., Zhang, J. Q., \& Athaide, G. A. (2018). Designing a Customer Experience Management Course. Journal of Marketing Education, v42 n2 p157-169.

Marutschke, D., Gournelos, T., \& Ray, S. (2019). Understanding Fluency and Friction in Customer Experience Management. In Predicting Trends and Building Strategies for Consumer Engagement in Retail Environments (pp. 88-108): IGI Global.

McColl-Kennedy, J. R., Zaki, M., Lemon, K. N., Urmetzer, F., \& Neely, A. (2019). Gaining Customer Experience Insights that Matter. Journal of Service Research, 22(1), 8-26.

Meyer ,C., \& Schwager, A. J. H. b. r. (2007). Understanding Customer Experience. Harv Bus Rev. 85(2), 116.

Moghaddam, A. (2006). Coding Issues in Grounded Theory. Issues in educational research, 16(1), 52-66.

Nambisan, S., \& Baron, R. A. (2007). Interactions in Virtual Customer Environments: Implications for Product Support and Customer Relationship Management. Journal of interactive marketing, 21(2), 42-62.

Olenius, L. (2013). Changing Tomorrow in Customer Experience. Master's Thesis in Business Administration. 1-79.

Palmer, A. (2010). Customer Experience Management: A Critical Review of an Emerging Idea. Journal of Services Marketing, 24(3), 196-208

Rahimi Baghlamak, J., Haghighi, M., \& Mira, S. A. (2019), "Designing and Explaining Loyalty Model Based on Customer Experience in Hotel Management Industry Through Usage Made of Grounded Theory Strategy", Journal of Commercial Management, 11(1), 125-140. Doi:10.22059/jibm.218111.2306.2018

Strauss, A., \& Corbin, J. M. (1990). Basics of Qualitative Research: Grounded Theory Procedures and Techniques, Sage Publications, Inc.

Zaki, M., \& Neely, A. (2019). Customer Experience Analytics: Dynamic CustomerCentric Model. In Handbook of Service Science, Volume II (pp. 207-233): Springer. 